\title{
Konferencja „Losy i znaczenie dziedzictwa po klasztorach skasowanych na obszarze Prus Zachodnich i Wschodnich oraz Pomorza", Przysiek pod Toruniem, 7-9 listopada 2013 roku
}

\section{(c) $($ ) $\odot$}

W dniach 7-9 listopada 2013 roku w Przysieku pod Toruniem odbyła się konferencja naukowa zorganizowana w ramach projektu „Dziedzictwo kulturowe po klasztorach skasowanych na ziemiach dawnej Rzeczypospolitej oraz na Śląsku w XVIII i XIX wieku: losy, znaczenie, inwentaryzacja" finansowanego w ramach programu Ministra Nauki i Szkolnictwa Wyższego (Narodowy Program Rozwoju Humanistyki w latach 20122016). Założeniem organizatorów konferencji - Marka Derwicha (Wrocławskie Towarzystwo Miłośników Historii i Instytut Historyczny Uniwersytetu Wrocławskiego), Waldemara Rozynkowskiego oraz Piotra Olińskiego (Instytut Historii i Archiwistyki Uniwersytetu Mikołaja Kopernika w Toruniu) - była prezentacja wyników badań związanych z projektem.

Po uroczystym otwarciu obrad i powitaniu gości pierwszy zabrał głos Marek Derwich, który w wystąpieniu: Bazy danych w projekcie „Dziedzictwo kulturowe po klasztorach skasowanych na ziemiach dawnej Rzeczypospolitej oraz na Ślasku w XVIII i XIX wieku: losy, znaczenie, inwentaryzacja”: sporządzanie $i$ korzystanie omówił główne cele projektu oraz zaprezentował jego część informatyczną, czyli portal projektu oraz bazę danych dotyczącą skasowanych klasztorów.

Pierwszy panel obrad poświęcony został kasatom reformacyjnym. Maja Gąssowska w referacie pt. Reformacja jako koniec monastycyzmu inflanckiego $w X V I w$. - zarys problematyki przedstawiła losy klasztorów inflanckich - ze szczególnym uwzględnieniem franciszkanów i dominikanów - likwidowanych decyzjami władz miejskich, zapadającymi pod wpływem reformacyjnych prądów i niejednokrotnie wiążących się z tumultami miejskimi. Następnie Krzysztof Guzikowski w wystąpieniu Kasata opactw cysterskich na Pomorzu Zachodnim omówił proces kasacji zakonów cysterskich na wska- 
zanym terytorium, zapoczątkowany decyzją sejmu w Trzebiatowie w 1534 roku. Prelegent zwrócił uwagę na znaczenie działalności Jana Bugenhagena w czasie tych kasat, podkreślił także łagodniejszy przebieg likwidacji zakonów żeńskich, ze względu na zwyczaj posyłania w ich szeregi córek bogatych rodzin szlacheckich. Z kolei Waldemar Rozynkowski w referacie pt. Dziedzictwo kulturowe po zakonie krzyżackim na obszarze Prus - wybrane zagadnienia zaprezentował pozostałości dziedzictwa kulturowego po zakonie krzyżackim, skupiając swoją uwagę na dziejach klasztornych kaplic i ich wyposażenia.

Kolejna część obrad dotyczyła materiału źródłowego związanego z kasatami zakonów. Wystąpienie Ewy Lichnerowicz - Druki i rękopisy z opactwa cystersów w Oliwie w zbiorach PAN Biblioteki Gdańskiej - stanowiło opis projektu inwentarza zbiorów pochodzących ze wskazanego w tytule klasztoru, z których większość znajduje się w zbiorach PAN Biblioteki Gdańskiej. W referacie pt. Mobilia ze skasowanych klasztorów dominikanów i karmelitów $w$ Gdańsku w inwentarzach zbiorczych akt kasacyjnych pruskiego Ministerstwa Wyznań w Geheimes Staatsarchiv Preussischer Kulturbesitz w Berlinie Sławomir Kościelak zaprezentował zestawienia wybranych mobiliów pozostałych po klasztorze dominikanów z kościołem św. Mikołaja oraz klasztorze karmelitów trzewiczkowych z kościołem św. Jana w Gdańsku na podstawie XIX-wiecznych inwentarzy sporządzonych przez samych zakonników. Karol Maciejko w swoim wystąpieniu pt. Archiwalia poklasztorne w zasobie Archiwum Państwowego w Olsztynie omówił elementy składowe dwóch zespołów archiwalnych pochodzących ze skasowanych klasztorów (zespoły: Klasztor Ojców Bernardynów w Lubawie oraz Klasztor Ojców Bernardynów w Barczewie). Autor omówił stan zachowania dokumentów oraz zwrócił uwagę na informacje dotyczące zakonnej spuścizny, które można znaleźć w aktach urzędowych. Na koniec Karolina Stanilewicz w referacie pt. Paramenty sióstr norbertanek $w$ Żukowie - ich losy po kasacie klasztoru i znaczenie dla rozwoju kultury artystycznej Pomorza przedstawiła historię pracowni hafciarskiej oraz nieliczne zachowane hafty sióstr norbertanek. Prelegentka wskazała, że siostry, ucząc sztuki haftowania, przyczyniły się do rozwoju hafciarstwa w regionie, przez co także oddziaływały na kulturę kaszubską.

Drugi dzień obrad rozpoczął panel zatytułowany „Przed i po kasacie”. Pierwszy zabrał głos Rafał Kubicki, który w wystąpieniu zatytułowanym 
Wybrane źródta dotyczace kasaty klasztorów bernardyniskich $w$ Prusach Zachodnich w pierwszej potowie XIX w. przedstawił etapy charakterystyczne dla procesu kasaty klasztorów, wskazał związane z tym typy dokumentacji oraz zwrócił uwagę na kierunki dalszych prac, a więc możliwość rekonstrukcji materialnej spuścizny czy odtworzenia składu osobowego konwentów. Referat Piotra Olińskiego pt. Spory benedyktynek toruńskich z wtadzami pruskimi w związku z dziataniami kasacyjnymi dotyczył przebiegu sporu benedyktynek toruńskich z władzami miasta o folwark Golubski (część wsi Mokre). Badacz poświęcił swoje rozważania m.in. prawnym aspektach konfliktu, w tym ocenie zapadłego wyroku, przyznającego majątek benedyktynkom.

Kolejne referaty prezentowały procesy likwidacyjne oraz dzieje poklasztornych spuścizn. Leszek Zygner (Kasata klasztorów w diecezji ptockiej pod pruskim panowaniem) przedstawił przykłady dwóch skasowanych klasztorów ze wskazanego obszaru - franciszkanów konwentualnych w Wyszogrodzie oraz dominikanów w Płocku, upatrując genezy ich likwidacji w polityce kolonizacyjnej władz pruskich. Andrzej Buczyło wygłosił referat poświęcony kasacie klasztoru karmelitów trzewiczkowych w Bielsku Podlaskim (Kasata i losy pokasacyjne klasztoru karmelitów w Bielsku Podlaskim). Rafał Witkowski (Kasata kartuzji Domus Paradisi Mariae i losy majątku poklasztornego) dokładnie zanalizował przebieg kasaty klasztoru kartuzów z Raju Maryi pod Gdańskiem, uwzględniając przy tym analogie do kasaty klasztoru cystersów w Pelplinie. Z kolei Maksymilian Kuśka (Likwidacja klasztorów braci mitosiernych w Gdańsku i Łowiczu i dziedzictwo po nich pozostate) omówił dzieje i kasatę dwóch klasztorów bonifratrów, podkreślając przy tym fakt, że zachowało się po nich wyjątkowo mało źródeł i innych świadectw ich istnienia.

W części poświęconej losom druków i muzykaliów znalazło się wystąpienie ks. Wojciecha Zawadzkiego pt. Księgozbiory klasztorów męskich w Prusach Zachodnich w okresie ich kasaty, w którym badacz szczegółowo przedstawił koleje losów oraz stan księgozbioru pozostałego po kasacie klasztorów franciszkańskich na wskazanym obszarze. W kolejnych wystąpieniach prelegentki przedstawiły wydarzenia dotyczące pokasacyjnych losów następujących budowli: Katarzyna Błoch - klasztoru w Trzemesznie (Zespót poklasztorny $w$ Trzemesznie. Stan badań archeologiczno-architektonicznych i perspektywy badawcze), Joanna Napierała - kolegium jezuickiego w Poznaniu (Losy zabudo- 
wań kolegium jezuitów w Poznaniu po jego kasacie w 1773 r.), Anna Niklas - kościoła reformatów w Grudziądzu (Historia i architektura dawnego kościota reformatów w Grudziadzu), Anna Cicha - klasztoru benedyktynek w Toruniu (Klasztor benedyktynek toruniskich - od spichrza do muzeum).

Ostatni panel konferencji dotyczył dziejów wyposażenia artystycznego skasowanych zakonów. Bożena Grabowska w swoim wystąpieniu zatytułowanym Losy dziedzictwa po opactwie cystersów w Mironicach (sekularyzowane $w 1539$ r.) opisała obiekt znany jedynie z rycin, planów oraz badań archeologicznych. Z kolei Witalij Rosowski w referacie pt. Z Kresów Wschodnich na Ziemie Odzyskane. Losy cudownego obrazu Pana Jezusa z klasztoru ojców reformatów w Dederkatach na Wotyniu przedstawił dzieje klasztoru, zwracając uwagę na historię skradzionego w latach osiemdziesiątych XX wieku cudownego obrazu Pana Jezusa Ukrzyżowanego. Ostatni referat - Pokasacyjne losy kompozycji krajobrazowych cystersów oliwskich - wygłosiła Małgorzata Milecka. Omówiono w nim stan dobrze zachowanego parku w Oliwie, łączącego w swoich założeniach różne style i kompozycje roślinne.

Zebrani goście mogli także przeczytać referaty nieobecnych uczestników konferencji: Rafała Simińskiego (Kasata klasztoru norbertanów w Biatobokach w pierwszych dziesięcioleciach XVI wieku), Rolanda Prejsa (Kasata klasztoru kapucynów w Rywatdzie - losy mienia poklasztornego) oraz Paoli Picardi (The fate of the artistic heritage of the Pope's villa at the Magnalia and convent of Santa Maria della Concezione in Campo Marzio: cases of dissolution of monasteries in Rome after 1870).

Wspólne obrady w gronie reprezentantów różnych dziedzin - m.in. historii, historii sztuki, archeologii - wywoływały burzliwe dyskusje i przyniosły propozycje współpracy i dalszych badań. Interdyscyplinarne spotkanie dowiodło konieczności prowadzenia wspólnych i wzajemnie uzupełnianych badań w zakresie podjętego tematu. Podsumowując obrady, Marek Derwich wyraził potrzebę możliwie szerokiego udostępniania informacji o zachowanych aktach i archiwaliach i innych świadectwach poklasztornych, które nie tylko dla historyków, ale również przedstawicieli innych dziedzin nauki okazują się często trudno dostępne. 